European Journal of Marketing, 2009, Vol. 43, No. 7/8, pp.890-906

\title{
The changing role of sales: viewing sales as a strategic, cross-functional process
}

\begin{tabular}{|c|c|c|c|}
\hline $\begin{array}{l}\text { Professor Kaj Storbacka } \\
\text { Professor of Market } \\
\text { Strategy } \\
\text { Hanken School of } \\
\text { Economics } \\
\text { P.O. Box 479, FIN- } \\
\text { 00101 Helsinki, Finland. }\end{array}$ & $\begin{array}{l}\text { Professor Lynette Ryals* } \\
\text { Professor of Strategic Sales } \\
\text { and Account Management } \\
\text { Cranfield School of } \\
\text { Management } \\
\text { Cranfield, Beds., MK43 0AL } \\
\text { UK }\end{array}$ & $\begin{array}{l}\text { Dr Iain A. Davies } \\
\text { Research Fellow in } \\
\text { Marketing } \\
\text { Cranfield School of } \\
\text { Management } \\
\text { Cranfield, Beds., MK43 } \\
\text { OAL } \\
\text { UK }\end{array}$ & $\begin{array}{l}\text { Suvi Nenonen } \\
\text { Doctoral student } \\
\text { Hanken Swedish School } \\
\text { of Economics and } \\
\text { Business Administration } \\
\text { PO Box } 479 \\
\text { FI-00101 Helsinki } \\
\text { Finland }\end{array}$ \\
\hline $\begin{array}{l}\text { Tel+358-500446733. } \\
\text { Email: } \\
\text { kaj.storbacka@hanken.fi. }\end{array}$ & $\begin{array}{l}\text { Tel: +44 } 1234751122 \\
\text { Fax: +44 123475 } 1806 \\
\text { lynette.ryals@cranfield.ac.uk }\end{array}$ & $\begin{array}{l}\text { Tel: } 0044 \text { (1)234 } 7511 \text { 22* } \\
\text { Fax: } 0044 \text { (1)234 } 751806 \\
\text { iain.davies@cranfield.ac.uk }\end{array}$ & $\begin{array}{l}\text { Tel: +358505626028 } \\
\text { Fax:+358207789371 } \\
\text { suvi.nenonen@hanken.fi }\end{array}$ \\
\hline
\end{tabular}

* Lead author for correspondence

Research paper

Submitted to: $\quad$ European Journal of Marketing Special Issue on the $21^{\text {st }}$ century sales function

Submission date: $\quad 1^{\text {th }}$ June 2007

Second submission: $15^{\text {th }}$ January 2008

Third submission: $\quad 5^{\text {th }}$ June 2008

Word count: $\quad \mathbf{6 , 4 5 0}$ excluding abstract, table and references 


\section{Author biographies:}

\section{Prof. Kaj Storbacka DSc(Econ) MSc}

Kaj Storbacka is Professor of Market Strategy, Hanken School of Economics, and board member of CERS, Centre for Relationship Marketing and Service Management at Hanken School of Economics, Finland. He is a board member of the Strategic Account Management Association, Chicago, Illinois. His main research interests include strategic account management, customer asset management, customer profitability and relationship marketing.

\section{Prof. Lynette Ryals MA (Oxon) MBA PhD FSIP}

Lynette is Professor of Strategic Sales and Account Management and Director of the Demand Chain Management Community at Cranfield School of Management, UK. She is the Director of Cranfield's Key Account Management Best Practice Research Club. Her research interests include sales and key account management, particularly in the areas of customer profitability; risk; and customer portfolio management.

\section{Dr. Iain Davies BSc PhD}

Iain is a research fellow in marketing at Cranfield School of Management, UK. He has more than ten years' experience in ethical trade and a $\mathrm{PhD}$ in strategy and marketing from the International Centre for Corporate Social Responsibility at Nottingham University. Before joining Cranfield, he was a Management Consultant in a world renowned consultancy. His research interests include business to business relationships, ethical brand creation and networked value creation.

\section{Suvi Nenonen MSc (Econ)}

Suvi is a doctoral student at Hanken Swedish School of Economics and Business Administration. Her thesis examines how customer portfolios can be used in customer asset management in a business-to-business context. Her research interests include customer asset management, customer portfolios and strategic account management. 


\section{The changing role of sales: viewing sales as a strategic, cross-functional process}

\section{Structured abstract}

Purpose of the paper: Although there is substantial practitioner evidence for changes in the role and functioning of sales in the $21^{\text {st }}$ century, there is little academic research charting new directions for the sales function in a business-to-business context.

Approach: This paper reports on four case studies that illustrate how sales is changing.

Findings: The results demonstrate that sales is changing in three interrelated aspects: from a function to a process; from an isolated activity to an integrated one; and is becoming strategic rather than operational.

Limitations and implications: The results suggest that changes in the role of sales will affect sales processes and the way that the sales function liaises with other departments.

Key words: sales function, sales process, sales organisation, case study 


\section{Introduction}

Sales is shifting from a $20^{\text {th }}$ century "selling products and services" model to a $21^{\text {st }}$ century model in which salespeople focus on increasing customer productivity (Leigh and Marshall, 2001). Piercy (2006) categorises this change as the emergence of the strategic sales organization, where sales converges with marketing to take on greater strategic significance to the organization. Harvard Business Review's special issue on sales (2006, Vol. 84 No. 7/8) argued that sales is becoming a strategic activity in which the sale is made with the intention of building and maintaining a long-term relationship. Thus, the salesperson is increasingly acting as a relationship manager rather than as the traditional order-taker.

Our paper examines the change in the role of business-to-business sales, its functions and processes, through four case studies of organizations that have transformed their sales function and improved their performance as a result. This article is structured as follows: first, we discuss literature relating to the changing role of sales, the connection between sales strategy and business strategy, the demands on the sales process, and the interaction between sales and other functions of a firm. Second, we describe our research process and methodology. Third, findings from the case studies are described and discussed. Finally, we discuss the contribution of the article and identify managerial implications and future research opportunities.

\section{The role of sales}

Business-to-business marketing is increasingly identified with customer communication, branding, advertising, websites, point of sale materials etc. Sales, in a 
business-to-business context, is increasingly associated with account management and solution development. With the growth of online business-to-business order processing and replenishment, many transactions are now effectively managed by the marketing or IT function. Thus, order-taking - traditionally a sales preserve - has effectively become a marketing or operational task. The number of customers placing orders over the internet is dwarfed, however, by those who search for product information online before placing orders through other channels. In this way, the role of product knowledge and information specialist, formerly part of the salesperson's role, has been transferred to marketing or customer service, where the management of the website often resides.

By contrast, the sales function is increasingly taking on a relationship management role. Perhaps the most noticeable manifestation of this in business-to-business selling is in the emergence of Key Account Management (KAM) or Strategic Account Management (SAM) as a strategic sales activity, driven by issues such as increasingly sophisticated customers (McDonald et al., 2000), profit failures in manufacturing (Wise and Baumgartner, 1999) and commoditisation caused by short-termism (Lombardi, 2005). The key account manager has become custodian of the customer relationship, pursuing consultative and solution selling activities. The role of the key account manager is not just to sell new products and services but also to manage the ongoing relationship, to co-ordinate delivery and customer service, and to oversee the profitability (not just the revenues) of the relationship (McDonald et al.,2000).

However, with the exception of the KAM area there has been little empirical work exploring the changing role of sales, particularly in respect of the increasingly 
important role played by sales strategy. There are also implications for the sales process and, through this, for the interface of sales with other business functions.

\section{Sales strategy and business strategy}

Darrell Zahorsky from About.com (e.g. New York Times Group) identifies sales strategy as "the planning of sales activities: methods of reaching clients, competitive differences and resources available". This is similar to common definitions of marketing planning (e.g. McDonald, 2007) and demonstrates the need for an internal perspective as well as external perspective in customer management.

Gosselin and Heene (2003) argue that, through a strategic interface with clients, change should occur in the sales strategy itself. Homburg et al. (2000) even go on to discuss how these new sales strategies lead to organizational change. In its most complete form this would lead to corporate strategy placing full responsibility for customers (as the company's greatest asset) in the hands of salespeople, entrusting them to act as arbiters of these assets (Ingram et al., 2002). In essence, the salesperson would need the power to drive the activities in other functional areas and thus play a fundamental role in organization-wide strategy.

The vital role of sales as a strategic function of market-orientated organizations has been previously identified in the literature (Shapiro et al., 1994; Leigh and Marshall, 2001). There is a growing body of research linking sales strategy and marketing strategy. Thus, we see research highlighting the importance of aligning marketing strategy and sales objectives (Strahle et al., 1996); how collaboration between marketing and sales enhances business performance (Le Meurnier-Fitzhugh and Piercy, 2007; Guenzi and Troilo, 2007); and the importance of teaching marketing 
and sales planning to marketers (Reed et al., 2004). These are often approaches led by marketing strategy, in which sales strategy is linked indirectly to business strategy.

Research directly linking sales strategy to business strategy is less common. Rare exceptions include Leigh and Marshall (2001), who argue for the strategic role of sales; and Olsen et al. (2001) who identify the need for sales strategies to fluctuate with overall company strategy, with success reliant on senior sales managers being well-informed about business strategies and given the resources to match company objectives. Another example is Harker and Harker (1998), who identified good strategic sales management as the principal factor in the successful turnaround of a struggling company, as sales managers were given strategic responsibility for managing cash flow at a critical juncture. Yet these studies are few and far between.

This may change, however. Sales strategy is increasingly discussed in the academic literature (Eisenhardt and Martin, 2000), including strategic issues concerning cocreation of value (Singh and Rhoads, 1991) and alliance and network creation (Dyer and Singh, 1998). Clearly, sales strategies have implications for the sales process and for the interface of sales not just with customers but also within the organisation.

\section{The sales process}

As customers become more sophisticated and better-informed (McDonald et al., 2000), the sales process is much less about selling a product and much more about creating a relationship. There has been an accompanying shift from product to service (or solution) selling ("servitisation”) in many business-to-business interactions (Vargo 
and Lusch, 2004). The emergence of servitisation has inevitably widened the constituency that is involved in the sales and subsequent delivery processes. For salespeople to succeed in a servitised sales process they require knowledge held not just by marketing (unique selling features, value in use, competitive advantage, segmentation, branding) but also by operations (product issues, production scheduling, quality control, R\&D, delivery timeliness and reliability), and finance (profit and loss information) resulting in the need for greater internal communication.

At the same time, however, salespeople performing boundary-spanning roles such as KAM (McDonald et al., 1997) are in a position to increase flows of valuable information back to their companies. According to Festervand et al. (1988), there are compelling reasons for including the sales force in the design and operation of market intelligence systems, including the intimacy of their relationship with the customer, and the low costs of exploiting this type of market information. In addition, salespeople are able to provide early insights into the activities of competitors, as well as other marketplace changes. Despite this, many organizations fail to analyse competitor intelligence collected from or by the sales force, or to integrate this data into the general market intelligence system (Festervand et al., 1988). Still worse, salespeople may be reluctant to pass information on to marketing if there is no clear benefit to them in so doing (Homburg et al., 2000).

The literature therefore suggests that the process of business-to-business selling must be two-way, firstly collecting customer information and requirements and feeding them back to their own organization and secondly collating organizational knowledge and resources. However, the interaction of sales with functions other than marketing 
has received little attention in the literature, despite its criticality to the emerging servitisation debate.

\section{Sales interaction with other functions}

There is general agreement that improvements in the relationship between sales and marketing would be beneficial to the organization in terms of improved business performance (e.g. Cespedes, 1993; Dewsnap and Jobber, 2000; Rouzies et al., 2005; Kotler et al., 2006). For example, Tjosvold (1988) found that collaboration between these departments led to improved productivity and competitiveness. Improvements in collaboration, interdepartmental relations, and communication quality may enhance the formulation of strategy, as well as reduce conflict (Menon et al., 1996).

Far less attention has been paid to the interaction between sales and other functional departments (Hulbert et al., 2003). Homburg et al. (2000) identify the overcoming of functional boundaries and (often) the development of cross functional teams as important facets of customer focused organizations. The account management literature provides the clearest indication of the drive for integration with other functions, because of the role the account manager plays in ensuring customer profitability (McDonald et al.,2000) and therefore in integrating and reconfiguring resources from other functional departments to satisfy customer requirements (Eisenhardt and Martin, 2000). Piercy (2006) comments briefly on this need but returns to the marketing interface as the most important area of integration for sales. In terms of consistency of customer communication this makes sense, but from a promise delivery perspective it is operational functions that should be aligned with sales strategy. 


\section{Research design}

Recent research has indicated that sales is changing and that there is increasing highlevel pressure on the sales force to become more effective (Atkinson and Koprowski, 2006). Yet sales has generally been an under-researched area in relation to its marketing, logistics and strategy colleagues. There is a need for case-based research to demonstrate the functioning of, and the potential for, the new sales role.

\section{Methodology}

The lack of existing empirical work on which to ground this research meant it was decided to follow an exploratory line of enquiry, developing theory through an unstructured interpretive approach (Hassard, 1993; Miles and Huberman, 1994), and allowing theory to emerge from the research data (Glaser, 1992). An action research approach was selected as this is acknowledged in the literature as a valuable method for understanding organizational change (Coghlan and Brannick, 2001; Gummesson, 2001). In the research context, action research allows collaborative problem solving with those involved and the generation of new knowledge (Coghlan and Brannick, 2001). The researchers worked alongside each organization in a collaborative effort to understand and improve the sales process (following Gummesson, 2001).

Both Normann (1977) and Schein (1987) suggest that the improvement of the organization is the ultimate test of validity for [clinical] research. Thus, where the data are available, the collaborative case studies report on the results that the companies experienced. 


\section{Participating companies}

In case study research the context is important (Patton and Appelbaum, 2003). The organizations were all large global companies who were changing their existing sales process to adapt to changing circumstances. The organizations comprised four global industries: construction (Company A), power solutions (Company B), building technology (Company C), and electronics and software (Company D). These industries were selected because of the critical role of the sales force, the lengthy and adaptive sales process that involved solution selling and a moderate to high degree of customisation, the scale and complexity of the customer relationships involved, and because the formal and expensive nature of the sales process meant that there was the potential for a major pay-off to improving the sales process.

The interaction with the organizations involved senior level executive vice presidents, and senior managers involved in managing the sales process. Considerable efforts were made to identify 'reflective practitioners' (Schön, 1983; Gummesson, 2002) who expressed an interest in involvement in conceptual development. The research followed the four-stage model proposed by Zuber-Skerritt (1992): "Plan" (exploration of the context ); "Act" (intervention); "Observe" (physical data collection including research notes, secondary sources and formalised interviews); and "Reflect" (analyzing the collected data and identifying themes that inductively feed into the "plan" activity of a new iteration).

\section{Data reduction and analysis}


The observed data were analysed through an iterative process of categorisation and abstraction described by Thomas (1993). Reflection, the principle form of analysis in this research, is non-linear, non-sequential, iterative process of systematic combination that aims to match theory with reality (Dubois and Gadde, 2002; Eisenhardt, 1989). Reflection involved two main stages. Firstly, an independent review of the data collected from the four cases identifying themes relevant to sales change was carried out. The second stage then involved the researchers comparing the cases dispassionately and debating whether and how each data item should be included in the analysis. These debates ensure "theoretical sensitivity" (Glaser, 1992; Strauss \& Corbin, 1998) and involve clarifying the meaning, wording and linking between data points, themes and actions.

The analysis of results was based on inductive logic and drew on recommendations by Glaser and Strauss (1967), Miles and Huberman (1994), and Strauss and Corbin, (1998). Analysis was based on a constant comparative approach (Barnes, 1996), meaning as the research proceeds, new data are collected and constantly compared to prior data and theory in terms of categories and concepts. This process is repeated until theoretical saturation is reached, i.e., until no new themes are generated out of the comparison of new and existing data and theory.

\section{Case findings: three continuums of change}

Throughout the four cases three strong themes emerged regarding changes the companies were having to make regardless of their sales sophistication (by 'sophistication' we mean the extent to which sales had been engineered to match customer requirements such as the use of strategic account management, customer 
relationship management programs / systems and customization of product offerings). These three themes are best conceptualized as three, somewhat interdependent, continuums:

1) From function to process: from sales as an independent function to sales as a pivotal part of a long term process of customer management.

2) From isolated to cross-functional: from isolated sales departments with little cross-functional influence to an integrated sales department with links to other activities such as finance, marketing and operations.

3) From operational to strategic: from operationally focused to a solution selling, strategically-focused part (and possibly principal part) of business strategy.

As we describe each of the four cases in greater depth, the extent to which these themes emerge becomes increasingly clear. In terms of sales sophistication; companies A and B had relatively unsophisticated sales functions, whereas C and D were already fairly sophisticated. All four companies, however, adapted their sales function along these three continuums.

\section{Case A: Construction Company}

Company A is one of the world's leading construction companies, operating throughout Europe and in the Americas. This case study describes company A's operations within a single country unit (all country units of Company A are legally independent companies). The case illustrates the changing role of sales driven by a change in corporate and sales strategy. 
The nature of Company A's business has changed dramatically over recent years. In the past, it mainly carried out contract construction assignments based on a competitive bidding process that was lengthy, expensive and risky. Recently, Company A decided on a change in its sales strategy: to reduce the number of competitive bidding processes it entered whilst seeking to increase the number of cooperative contract construction assignments and project development assignments it bid for. In cooperative construction contracts, the construction company takes a broader role: finding the building lot; finding property investors to fund the build; designing; constructing; letting and sometimes building life-cycle management. Thus, in project delivery the construction company does not sell properties - it sells guaranteed cash flow to the property investors.

Because the company is no longer offering construction at lowest possible cost, but is tailoring solutions based on the purchaser or leaseholder needs, cooperative contracts require considerably more insight into customer needs as well as the development of capabilities in sales and project delivery. This has had an impact on Company A's sales process, requiring it to develop new sales competences, especially related to finance, and to reconstruct its value proposition from a property-based to a cash flowbased one.

Company A has organised its sales in a unique way: it has no dedicated sales personnel. Instead, it has project managers that are responsible both for selling new projects and for managing them. The guiding principle is that the same project manager manages the project from the initial bid to project finalisation. This approach has several advantages. First, project managers have the skills to discuss project 
details early in the sales phase. Second, as the same person manages both the sales and the project delivery phase, there are no information gaps that can occur when complex projects are handed over from sales to project delivery. Third, customers are able to form a deep relationship with the project manager as they know the project manager is going to be their main point of contact throughout the project.

One drawback to the project manager approach is where there are multiple project managers providing service for the largest customers. This can translate into uneven service levels and unsystematic sales and project delivery practices. To overcome this challenge, Company A is developing strategic account management, structured sales processes and pre-defined offer concepts. Its customer segmentation will be an important component in implementing these initiatives.

Company A can segment its customer base along three dimensions: property owners vs. property users; private sector vs. public sector; and different property end uses (e.g. retail, logistics, and manufacturing). The largest customers, both private and public sector, are nominated as strategic accounts.

It has developed four core sales processes based on its segmentation. The different property end uses are taken as the starting point for the development of pre-defined concept offerings that differ for different property end uses. These concepts are targeted mainly at those customers that are not frequent property builders or whose main business resides outside construction and property development (i.e. non-key accounts). The new processes require considerable cross-functional cooperation within Company A: in order to pre-package complex offerings, the project managers 
have to cooperate with designers, technical experts, construction experts, financial experts, and end use area experts. Additionally, the top management of Company A has to be involved in concept creation to ensure that the created concepts support the achievement of the overall business strategy.

The link between sales and finance is particularly interesting. At Company A, sales has a special role in corporate risk management. In the project development business, as in other businesses, there is a relationship between risk and return: the more risks the construction company is willing to assume, the higher their profits. However, its corporate guidelines prevent Company A from putting building lots onto its balance sheet. Therefore, the project managers and the financial experts have to cooperate closely to ensure that Company A has a risk position that does not exceed the risk limits set by top management but that optimises profit.

Early results suggest a positive pay-off in terms of risk reduction and revenue growth. Company A has removed some 'fail points' in its sales process and is growing strongly in a competitive and difficult market place.

\section{Case B: Power solutions provider}

Our second case study illustrates sales interaction with other functions. Company B is a global power solution provider previously organised purely around product business units. The power supply industry has been moving from a dual approach (equipment and service) towards power solutions. This has had a big impact on Company B's value proposition and internal organisation. Previously, there were two business divisions, each with its own salesforce. The equipment salesforce was focused on one- 
off projects whereas the service salesforce sold spare parts in a transactional manner but also offered long-term maintenance agreements.

In moving towards power solutions, it created a horizontal sales unit that included marketing, business intelligence, concept design, and customer relationship management. There were also sales personnel within the product units who collaborated in many sales cases with the horizontal unit. The majority of sales cases are therefore handled by cross-functional teams in which the product unit sales personnel focus on product expertise whilst the people from the Sales unit concentrate on customer understanding. In complex sales cases the sales team is even larger: the sales and product sales experts are joined by top management representatives and engineers who begin creating customer-specific product specifications early in the sales phase.

In addition, Company $\mathrm{B}$ created a separate solutions business unit alongside the traditional product business units, in order to provide a complete lifecycle service. The role of the solutions business unit is to pre-package the products and services of other business units into sellable solutions. The solution business unit also supports the sales and product business units in sales and project delivery. Company B has made a conscious decision to focus the efforts of the solutions business unit onto those customers that are more open to outsourcing and where Company B can create added value.

Company B has initiated strategic account management, but to date it has not progressed into corporate level systematic processes or changes in organizational 
structure. The most recent organizational change, however, has strong indirect links to strategic accounts. There is a considerable overlap between the solution customers and the strategic accounts so, in part, the solutions business has been created to provide enhanced service for its strategic accounts.

The most sophisticated solution created by the solutions unit, remote operations, requires deep integration both within company B and with the customers. In remote operation, Company B assumes full responsibility of the power systems operations at the customer site, ranging from power system installation to day-to-day operations and maintenance. In order to deliver remote operation solutions, company B has to have access to various resources and information typically controlled by the customer. Company B has used acquisitions to gain new resources and know-how in operating power systems, service operations, and maintenance operations. Gathering the information needed to run power systems operations, on the other hand, needs deep cooperation with the customer: company B has to have instant access to information on customer operations in order to be able to provide the customer with sufficient power levels at all times. The value proposition used to sell remote operations solutions is quite different from value propositions used to sell other company B products and services. While selling power systems company B usually argues the total cost of ownership during the lifetime of the system; in remote operations sales company B's value proposition is built around availability of power: company B promises to deliver the needed power level at all times.

Although the sales unit is separate from the product business units, the sales directors are closely involved in creating the business strategies for all these business units. 
Additionally, the sales directors are part of the extended executive board of Company

B. Company B also monitors sales and customer related metrics as an integral part of its management system. Metrics such as order intake and customer satisfaction are some of the key performance indicators (KPIs) continuously followed up by the top management. The KPIs show steady improvement and the company is performing strongly.

This is an illustration of a change to sales strategy that was enabled through the development of a networked sales function. However, these processes are highly complicated and have created considerable conflicts within the organisation. As a result, the company is considering a further organisational structure change to a customer segment organisation where sales and account management processes would be handled by sector-specialist teams who would own the customer relationship. In this revised structure, the product people will support the relationship team. This move will integrate the product business units into the relationship management process, although overall ownership of the relationship will belong to the relationship management team.

\section{Case C: Building technology provider}

The third case study illustrates a dramatic change in the sales process that arose from a change in sales strategy and that required sales to interface with other business functions. The changes resulted in a closer link between sales and corporate strategy.

Company $\mathrm{C}$ is a global building technology company with two divisions: new equipment sales, and service sales. Historically these two divisions operated with 
separate sales departments. Several years ago, Company C initiated a corporate-wide transformation programme aimed at achieving strong growth through increased customer-centricity. During this transformation program, the sales function was radically reformed in four respects: creation of cross-functional processes, development of a partnership program for strategic customers, re-definition of the role of its major project business unit, and integration of customer- and sales-related issues into corporate strategy and the management system.

The starting point for this transformation was a change in the definition of a customer. Company $\mathrm{C}$ decided that property developers, building owners, and facility managers were as important as the architects and construction companies that have primary roles in the construction process.

The transformation of the sales process was implemented through the development of a 'process hierarchy'. Four company-wide processes were identified: customer management, order and delivery, product and service management, and planning and support. Next, the core processes were analysed into their constituent processes. So, for example, the customer management process had four constituent processes: managing customer relationships, creating demand, selling, and delivering offering. Once these constituent processes were identified they, in turn, were divided into subprocesses, work flows and procedures.

Within the customer management process, Company $\mathrm{C}$ identified nine roles, of which five (including key account managers and sales managers) reside within the traditional domain of the sales function. However, four other roles lay outside the traditional 
sales domain (marketing manager, global marketing, technician/supervisor, engineering, and top management). This analysis revealed the need for Company $\mathrm{C}$ to manage sales as a cross-functional process rather than a set of functional activities. The way that the role of a service technician changed illustrates the transformation of Company C's sales from functional to cross-functional process. In the past, the service technicians had visited customer sites purely to perform service operations. The service technicians were trained to identify sales opportunities while they worked on customer sites; for example, a service technician could identify customer needs for a larger service package, or equipment modernisation. Based on the magnitude of the identified sales opportunity, the service technician relays the information to the appropriate sales manager or account manager. Expanding the role of a service technician to a cross-functional one has enabled Company $\mathrm{C}$ to increase its service sales considerably.

Company C's sales transformation also involved the development of a partnership programme. It has selected a small number of strategic customers out of its global customer base based on relationship volume, relationship profitability, relationship strength, growth potential, and learning potential. These strategic customers bring in $30 \%$ of the total corporate turnover. The objective of the partnership program is to ensure a collaborative cross-functional and cross-business unit approach within Company $\mathrm{C}$ that exploits all opportunities for cross-selling, up-selling and additional sales while ensuring that the strategic customers achieve optimal performance of their machinery at minimum cost of ownership. All customers in the partnership program are offered access to Company C's top management. Annual relationship reviews are 
used to develop a deep understanding of the strategic customers and to create encounters that provide a natural platform for a management-level dialogue.

Company $\mathrm{C}$ offers twelve components in its partnership program. These components (such as budgeting, customised service scheduling and remote monitoring services) define the customer-specific solution for each customer in the partnership program. The components are designed in a way that creates value to both the customer and Company C. For example, the budgeting service ensures that the customer has its installed base of machinery serviced and modernised according to regulations and at the minimum total cost of ownership, whilst simultaneously providing the supplier with insight about the future service and modernisation needs of the customer.

Company $\mathrm{C}$ has also changed the role of its major projects unit into a cross-functional business unit that focuses on large-scale projects related to the construction of new shopping centres, large buildings and airports. These large projects do not always come from the strategic customers and therefore are not eligible for the partnership program. The major projects unit packages all Company C's products and services from all business units. Moreover, considerable cross-border and cross-functional cooperation within Company $\mathrm{C}$ is needed to sell major projects: the major projects are sold globally from the major projects unit; and sales, engineering and top management have to cooperate closely in order to win a case that can consists of hundreds of machinery specifically engineered for the customer.

An essential aspect of the success of Company C's new sales process is its integration with strategy and management. The executive board of Company $\mathrm{C}$ has set defined 
objectives and milestones for all strategic sales initiatives, and the progress of these initiatives is followed up in every executive board meeting. In addition, the main operational metrics were changed to include more sales and customer related metrics. Today, the executive board tracks sales and customer metrics such as: the number of sales calls, growth of the number of service contracts in selects segments, growth of order volumes from strategic customers, and the cancellation rate for service contracts.

Company $\mathrm{C}$ has achieved substantial business performance improvements after it initiated its transformation program. Two years into the transformation, sales to strategic customers have grown over three times as fast as overall revenue growth. Additionally, the company's share of spend has increased and customer loyalty has improved.

\section{Case D: Electronics and software provider}

The case of Company D illustrates the integration of sales and corporate strategy internationally, and the consequent development of an international sales process.

Company $\mathrm{D}$ is one of the leading electronics and software providers in the world and has a long history in implementing strategic account management: the company launched its first strategic account teams during the 1990's. Initially, the strategic account teams focused mainly on providing service to strategic customers within the country borders, which meant that international strategic customers might be managed by several account teams working in different countries. 
During the 1990's the company grew rapidly, and the complexity of the offering increased considerably. Faced with its growing international business and a highly complex offering consisting of hardware, software and service components, company D decided to systematize its account management and sales processes. Prior to this, company D had already created company-wide processes for project delivery. Therefore the company had already gained experience in designing and implementing global processes.

Historically, the business units of company D were geographically defined and the profit and loss was primarily calculated on these geographical business units. Now, however, Company D has created a separate horizontal unit that accommodates all the strategic account teams. The director of this unit is a member of the company's executive board.

Given that a large customer can generate annual revenues of tens of millions of Euros, Company D now conducts business planning in two directions: geographical business units and strategic accounts. It uses a two-fold management system to align the operations of business units and strategic account teams. Biannual target setting for both business units and strategic account teams consists of three components: volume, profit and non-monetary targets. The non-monetary targets are intentionally used to create alignment between the business units and the strategic account teams. For example, a business unit might receive a non-monetary target to win a certain sales case that is not top priority from the business unit viewpoint, but is strategic for the strategic account team and the company. 
The second part of the management system concentrates on aligning the sales cases between business units and strategic account teams. Both the business units and strategic account teams have their own lists of hot prospects, but the hot prospect lists and the unit targets are stored in a common database. For all major sales cases the decision whether to bid or not is made jointly between the business unit and the strategic account team. If the two units are unable to reach an agreement, there is a documented escalation process through which the 'bid-no bid' decision is transferred to higher organizational levels in both the business unit and the strategic account team. The 'bid-no bid' decision is crucial for Company D's business as it is not uncommon for investment in a sales process to reach several million Euros.

Company D utilises a three-tier hierarchy in categorising its strategic customers. The customer categorisation is mainly based on current business volume. For top tier strategic customers, company D created a multi-functional global account team consisting of an account director (a senior management position), account controller (finance and accounting), marketing director, care manager (after sales service), and project manager (project delivery). The tier two and three account teams incorporate fewer roles than the top tier account teams, but all account teams incorporate multiple functional and service competences.

The strategic account teams create long-range strategies for their strategic customers. One of the most important inputs to this is the joint offering and technology roadmap shared between Company D and its strategic customers. Roadmap sharing has several benefits for the supplier. First, these strategic discussions about future technologies open up a natural forum for top management dialogue. Next, the ability to influence 
customer roadmaps makes it possible for company $\mathrm{D}$ to consolidate its position as one of the main suppliers of its strategic customers. In fact, joint reviews of customer roadmaps enable company D to affect the future of the entire industry. Moreover, roadmap comparisons act as an effective screening board for new technologies, preventing Company D investing in technologies none of its customers buy in to. Through roadmap sharing, Company D's strategic account teams are in a strong position when making corporate level decisions to invest in new capabilities and technologies, thus affecting the direction of corporate strategy.

Company D's industry is subject to volatile business cycles. To counteract this volatility, Company D set 'increasing the share of service business' as one of their main corporate objectives. The strategic account management programme has been crucial in achieving this objective. The majority of new service ideas have been generated through discussion with the company's strategic customers and the resulting services have usually been systematised in pilot projects with strategic customers. In this way, strategic account management has been pivotal in implementing company D's corporate strategy and in its success.

\section{Summary and discussion}

A cross-case analysis reveals three important aspects in which $21^{\text {st }}$ Century sales is changing (Table 1). The first aspect is that sales is increasingly about process, rather than a series of separate transactions carried out by a specific function. New features of the account management process relating to profitable delivery of customer value mean that there is no fixed start- or end-point in the sales process. Instead it flows as an integrated relational process from customer information, to operational 
mobilisation, to delivery. Although all four companies were in industries typified by long-term relationships, their salesforces previously operated in a short-term transactional manner. The cases suggest that, in some companies, the traditional sales role may fade away to be replaced by project managers, as in Company A and, to an extent, in Company C.

\section{Take in Table 1}

The second, related, aspect is the transformation of sales from isolation to crossfunctional. These case studies emphasize the increasingly close working links between sales and operations, as sales becomes linked with delivery. The other intriguing light that these cases shed on the changing practice of sales is the success that can come from integrating supplier and buyer companies. This integration is not just about delivery (Companies A and B), but also about integrating with the strategic customer's future planning through a shared roadmap (Company D). This should in turn both enhance delivery and improve sales forecasting accuracy. Company $\mathrm{C}$ also illustrates the role that sales can play in new product development, which may benefit not just the relationship in which the development takes place but could also increase opportunities within other customer relationships. Crucially, the important internal sales interfaces supporting this change were not with marketing but with delivery, finance and operational engineers, areas that has received only marginal comment in extant literature.

The third aspect in which sales is changing in these case companies is in a shift from an operational to a strategic activity. This is reflected in the increasing emphasis on customer issues and also on sales metrics at Board level across all four case 
companies. Interestingly, as the case of Company $\mathrm{C}$ shows, this may also have an impact on risk. Indeed, recent research has identified both supplier and customer dependency as an issue in closer buyer-supplier relationships (Ryals and Rogers 2006).

The analysis reveals that the case study companies are at different maturity stages in terms of their sales sophistication, suggesting a development lifecycle in the changing face of sales. Company A is at the early stages of sophistication, just introducing specialist strategic account management and defined sales processes; Company B has initiated sales change programmes which may result in corporate-level processes and organizational structure change; Company $\mathrm{C}$ has a strategic account management programme; and Company D has sophisticated and differentiated sales and account management and highly-developed planning. Interestingly, however, each of the three aspects of changing sales (from function to process, from isolation to integration, from operational to strategic) are found in the companies with less advanced sales models as well as in the companies with more sophisticated approaches to sales and strategic account management.

These four case studies of companies which have decided to change their sales function have revealed three common themes: from function to process, from an isolated to a cross-functional activity; and from operational to strategic. The case studies suggest some new directions for $21^{\text {st }}$ century sales. In particular, in these solution selling and major account contexts, the marketing/sales interface is not the most important one, as might be expected in a traditional sales setting. Instead, the cases reveal that the really important cross-functionalities are with finance, 
manufacturing, supply, engineering, and servicing. More research is needed into the constituent parts of each of the three continuums, to explore the multiple interfaces that complex selling now requires and the implications for organisational structures. These case studies also suggest that companies are using new sales processes; more research is needed into how these processes work and what makes them successful (or not), particularly as organisations shift towards a consultative selling model in which the final product is co-created with the customer, rather than being pre-defined. Finally, the research presented here has thrown up some issues relating to the relationship between sales and business strategy and for salespeople themselves. Future research might examine the implications of these findings for the selection, training and reward of sales people. 


\section{References}

Atkinson, T. and Koprowski, R. (2006), "Finding the weak link", Harvard Business Review, Vol. 84 No. 7/8, pp. 22-25.

Barnes, D.M. (1996), "An analysis of the grounded theory method and the concept of culture", Qualitative Health Research, Vol. 6 No. 3, pp. 429-441.

Cespedes, F. V. (1993), "Coordination sales and marketing in consumer goods firms", Journal of Consumer Marketing, Vol. 10 No. 2, pp. 37-55.

Coghlan, D. and Brannick, T. (2001), Doing Action Research in Your Own Organization, Sage, London.

Dawes, P. L. and Massey, G. R. (2005), “Antecedents of conflict in marketing's cross-functional relationship with sales", European Journal of Marketing, Vol. 14 No. 11/12, pp. 1327-1344.

Dewsnap, B. and Jobber, D. (2000), "The sales-marketing interface in consumer packaged-goods companies: A conceptual framework", Journal of Personal Selling and Sales Management, Vol. 20 No. 2, pp. 109-119.

Dubois, A. and Gadde, L-E. (2002), "Systematic combining: an abductive approach to case research", Journal of Business Research, Vol. 55 No. 7, pp. 553-560.

Dyer J. H and Singh H. (1998), "The relational view: cooperative strategies and sources of interorganizational competitive advantage", Academy of Management Review, Vol. 23 No. 4, pp. 660-679.

Eisenhardt, K. M. (1989), "Building theories from case study research", Academy of Management Review, Vol. 14 No. 4, pp. 532-550.

Eisenhardt K. M. and Martin J. (2000), "Dynamic capabilities: what are they?", Strategic Management Journal, Vol. 21 No. 10\&11, pp. 1105-1121.

Festervand, T. A. Grove, S. J. and Reidenbach, R. E. (1988), “The sales force as a marketing intelligence system", The Journal of Business and Industrial Marketing, Vol. 3 No. 1, pp. 53-59.

Glaser, B. (1992), Basics of Grounded Theory Analysis: Emergence v Forcing, The Sociology Press, Mill Valley, CA.

Glaser, B.G. and Strauss, A.L. (1967), The Discovery of Grounded Theory, Aldine, New York, NY.

Gosselin, D. and Heene, A. (2003), "A competence-based analysis of account management: Implications for a customer-focused organization", Journal of Selling and Major Account Management, Vol. 5 No. 1, pp. 11-31.

Guenzi, P. and Troilo, G. (2007), "The joint contribution of marketing and sales to the creation of superior customer value." Journal of Business Research, Vol. 60 No. 2, pp. $98-107$ 
Gummesson, E. (2001), "Are current research approaches in marketing leading us astray?" Marketing Theory, Vol. 1 No. 1, pp. 27-48.

Gummesson, E. (2002), "Practical value of adequate marketing management theory", European Journal of Marketing, Vol. 36 No. 3, pp. 325-49.

Harker, M. and Harker, M. (1998), "The role of strategic selling in the company turnaround process", Journal of Personal Selling \& Sales Management, Vol. 18 No. 2, pp. 55-67.

Hassard, J. (1993) Sociology and Organisation Theory, University Press, Cambridge

Homburg, C. Workman, Jr. J. P. and Jenson, O. (2000), "Fundamental changes in marketing organization: the movement toward a customer-focused organizational structure", Journal of the Academy of Marketing Science, Vol. 28 No. 4, pp. 459-478.

Hulbert, J. M., Capon, N. and Piercy, N. F. (2003), Total Integrated Marketing: Breaking the Bounds of the Function, The Free Press, New York, NY.

Ingram, T. N., LaForge, R. W., and Leigh, T. W. (2002), "Selling in the new millennium: a joint agenda", Industrial Marketing Management, Vol. 31 No. 7, pp. 559-567.

Kotler, P. Rackham, N and Krishnaswamy, S. (2006), "Ending the war between Sales \& Marketing", Harvard Business Review, Vol. 84 No. 7/8, pp. 68-78.

Le Meunier-Fitzhugh, K. and Piercy, N. F. (2007), "Exploring collaboration between sales and marketing." European Journal of Marketing, Vol. 41 No. 7/8, pp. 939955.

Leigh, T. W. and Marshall, G. W. (2001), "Research priorities in sales strategy and performance", Journal of Personal Selling and Sales Management, Vol. 21 No. 2, pp. 83-93.

Lombardi, L. J. (2005), "Managing strategic customer relationships as assets", LIMRA'S MarketFacts Quarterly, Vol. 24 No. 1, pp. 23-25.

McDonald, M. (2007), Marketing Plans: How To Prepare Them, How To Use Them, Sixth edition, Butterworth-Heinemann, Oxford.

McDonald, M., Millman, T. and Rogers, B. (1997), "Key account management: theory, practice and challenges", Journal of Marketing Management, Vol. 13 No. 8, pp. $737-757$

McDonald, M., Rogers, B. and Woodburn, D. (2000), Key Customers: How to Manage them Profitably, Butterworth-Heinemann, Oxford. 
Menon, A. Jaworski, B. J. and Kohli, A. K. (1996), "Product quality: impact of interdepartmental interaction", Journal of the Academy of Marketing Science. Vol. 25 No. 3, pp. 187-200.

Miles, M. B. and Huberman, A. M. (1994), Qualitative Data Analysis: An Expanded Sourcebook second edition. Sage, London.

Normann, R. (1977), Management for Growth, John Wiley \& Sons, New York, NY.

Olson. E. M. Cravens, D. W. and Slater, S. F. (2001), "Competitiveness and sales management: A marriage of strategies", Business Horizons, Vol. 44 No. 2, pp. 25-30.

Patton, E. \& Appelbaum, S.H. (2003), "The case for case studies in management research". Management Research News, Vol. 26 No. 5, pp. 60-71.

Piercy, N. F. (1986), "The role and function of the chief marketing executive and the marketing department a study of medium-sized companies in the UK", Journal of Marketing Management, Vol. 1 No. 3, pp. 265-298.

Piercy, N. F. (2006), 'The strategic sales organization', The Marketing Review, Vol. 6, pp. 3-28.

Reed, G., Story, V. and Saker, J. (2004), "Business-to-business marketing: What is important to the practitioner?" Marketing Intelligence \& Planning, Vol. 22 No. 5, pp. 501-510.

Rosenbloom, B. and Anderson, R. E. (1984), “The sales manager: tomorrow's super marketer", Business Horizons, Vol. 27 No. 2, pp. 50-56.

Rouzies, D. Anderson, E. Kohli, A. K. Micheals, R. E. Weitz, B. A. and Zoltners, A. A. (2005), "Sales and marketing integration: a proposed framework", Journal of Personal Selling and Sales Management, Vol. 15 No. 2, pp. 113-122.

Ryals, L.J. and Rogers, B. (2006), "Holding up the mirror: the impact of strategic procurement practices on key account management", Business Horizons, Vol 49 No 1, pp. 41-50.

Schein, E. H. (1987), The Clinical Perspective in Fieldwork, Sage, Newbury Park, CA.

Schön, D. (1983), The Reflective Practitioner: How Professionals Think in Action, Basic Books, New York, NY.

Shapiro, B. P., Slywotsky, A. J. and Doyle, S. X. (1994), "Strategic sales management: a boardroom issue", Case \#9-595-018, Harvard Business School, Cambridge, MA, 1-23.

Singh, J and Rhoads, G.K. (1991), "Boundary role ambiguity in market-orientated positions: A multidimensional, multifaceted operationalization", Journal of Marketing Research, Vol. 28 No. 3, pp. 328-338. 
Strahle, W.M., Spiro, R.L. and Acito, F., (1996), "Marketing and sales: strategic alignment and functional implementation," Journal of Personal Selling \& Sales Management, Vol. 16 No. 1, pp. 1-20.

Strauss, A. \& Corbin, J. (1998), Basics Of Qualitative Research: Grounded Theory Procedures And Techniques, $2^{\text {nd }}$ edition, Sage, Thousand Oaks, CA.

Thomas, J. (1993), Doing Critical Ethnography, Sage, Newbury Park, CA.

Tjosvold, D. (1988), "Cooperative and competitive interdependence”, Group and Organizations Studies, Vol. 13 No. 3, pp. 27-289.

Vargo, S.L. and Lusch, R.F. (2004), "Evolving to a new dominant logic for marketing”, Journal of Marketing, Vol. 68 No. 1, pp. 1-17.

Wise, R. and Baumgartner, P. (1999) "Go downstream: the new profit imperative in manufacturing", Harvard Business Review, Vol. 77 No. 5, pp. 133-141.

Zuber-Skerritt, O., (1992), Action Research in Higher Education: Examples And Redirections, Kogan Page, London. 
Table 1: Comparison of the case study companies

\begin{tabular}{|c|c|c|c|c|}
\hline & Company A & Company B & Company $\mathrm{C}$ & Company D \\
\hline Industry & Construction & Power solutions & Building technology & Electronics and software \\
\hline $\begin{array}{l}\text { From function } \\
\text { to process }\end{array}$ & $\begin{array}{l}\text { No sales personnel but project } \\
\text { managers that are responsible for } \\
\text { both sales and project delivery }\end{array}$ & $\begin{array}{l}\text { - Sales is conducted as a process } \\
\text { both from sales organization and } \\
\text { product business units }\end{array}$ & $\begin{array}{l}\text { Defined customer management } \\
\text { process, including processes such } \\
\text { as 'manage customer } \\
\text { relationships', 'create demand', } \\
\text { 'sell' and 'deliver' }\end{array}$ & $\begin{array}{l}\text { - Defined customer management } \\
\text { processes: 'account management' } \\
\text { and 'sales' }\end{array}$ \\
\hline $\begin{array}{l}\text { From isolation } \\
\text { to cross- } \\
\text { functional }\end{array}$ & $\begin{array}{l}\text { - In process of creating complete } \\
\text { offering concepts: cross- } \\
\text { functionality needed in } \\
\text { development, sales and delivery }\end{array}$ & $\begin{array}{l}\text { - Remote operations of customer } \\
\text { systems requires deep integration } \\
\text { both internally and with the } \\
\text { customer } \\
\text { - Solution business unit supports } \\
\text { pre-packages solutions and } \\
\text { supports in sales and project } \\
\text { delivery }\end{array}$ & $\begin{array}{l}\text { - Partnership program for strategic } \\
\text { customers defines both cross- } \\
\text { functional customer management } \\
\text { and cross-functional solutions } \\
\text { - Separate cross-functional } \\
\text { business unit for major projects }\end{array}$ & $\begin{array}{l}\text { - Customer operations in matrix } \\
\text { with geographical BUs } \\
\text { - Goal alignment between strategic } \\
\text { customer teams and BUs } \\
\text { - Roadmap sharing with strategic } \\
\text { customers }\end{array}$ \\
\hline $\begin{array}{l}\text { From } \\
\text { operational to } \\
\text { strategic }\end{array}$ & $\begin{array}{l}\text { Cooperation with sales and top } \\
\text { management needed to find and } \\
\text { execute optimal balance between } \\
\text { profit potential and risk }\end{array}$ & $\begin{array}{l}\text { - Sales directors involved in } \\
\text { creating BU strategies } \\
\text { - Sales represented in the extended } \\
\text { executive board } \\
\text { - Sales \& customer metrics in the } \\
\text { main management system }\end{array}$ & $\begin{array}{l}\text { - Executive board defines } \\
\text { objectives and milestones for all } \\
\text { strategic sales initiatives; } \\
\text { progress of these initiatives is } \\
\text { followed up in all executive } \\
\text { board meetings } \\
\text { - Sales and customer metrics } \\
\text { included in the KPIs }\end{array}$ & $\begin{array}{l}\text { - Customer operations represented } \\
\text { in the executive board } \\
\text { - Capability investments largely } \\
\text { directed by strategic customers }\end{array}$ \\
\hline
\end{tabular}

